\title{
Corrigendum: Comprehending non-native speakers: theory and evidence for adjustment in manner of processing
}

\section{OPEN ACCESS}

Edited and reviewed by: Manuel Carreiras,

Basque Center on Cognition, Brain and Language, Spain

*Correspondence: Shiri Lev-Ari, shirilevari@gmail.com

Specialty section

This article was submitted to Language Sciences, a section of the journal Frontiers in Psychology

Received: 04 March 2015 Accepted: 20 April 2015

Published: 06 May 2015

Citation:

Lev-Ari S (2015) Corrigendum: Comprehending non-native speakers: theory and evidence for adjustment in manner of processing Front. Psychol. 6:574. doi: 10.3389/fpsyg.2015.00574

\section{Shiri Lev-Ari * \\ Psychology of Language, Max Planck Institute for Psycholinguistics, Nijmegen, Netherlands}

Keywords: corrigendum, psycholinguistics, non-native speakers, working memory, comprehension, expectations, top-down processing

\section{A corrigendum on}

Comprehending non-native speakers: theory and evidence for adjustment in manner of processing

by Lev-Ari, S. (2015). Front. Psychol. 5:1546. doi: 10.3389/fpsyg.2014.01546

The Acknowledgment Section in the original publication was incomplete. The full acknowledgment is:

The research was funded by National Science Foundation grant BCS-0849034 awarded to principal investigator Dr. Boaz Keysar, who also provided guidance in this project. We would like to thank Chloe Goldman for helping with running the studies and Sayuri Hayakawa for helpful comments on an earlier version of the manuscript.

Conflict of Interest Statement: The author declares that the research was conducted in the absence of any commercial or financial relationships that could be construed as a potential conflict of interest.

Copyright $(\odot 2015$ Lev-Ari. This is an open-access article distributed under the terms of the Creative Commons Attribution License (CC BY). The use, distribution or reproduction in other forums is permitted, provided the original author(s) or licensor are credited and that the original publication in this journal is cited, in accordance with accepted academic practice. No use, distribution or reproduction is permitted which does not comply with these terms. 